\title{
Interactions between wind and water erosion change sediment yield and particle distribution under simulated conditions
}

\author{
TUO Dengfeng $^{1}$, XU Mingxiang ${ }^{1,2 *}$, ZHAO Yunge ${ }^{2}$, GAO Liqian ${ }^{2}$ \\ ${ }^{1}$ State Key Laboratory of Soil Erosion and Dryland Farming on the Loess Plateau, Institute of Soil and Water Conservation, \\ Northwest A\&F University, Yangling 712100, China; \\ ${ }^{2}$ Institute of Soil and Water Conservation, Chinese Academy of Sciences and Ministry of Water Resources, Yangling 712100, China
}

\begin{abstract}
Wind and water erosion are among the most important causes of soil loss, and understanding their interactions is important for estimating soil quality and environmental impacts in regions where both types of erosion occur. We used a wind tunnel and simulated rainfall to study sediment yield, particle-size distribution and the fractal dimension of the sediment particles under wind and water erosion. The experiment was conducted with wind erosion firstly and water erosion thereafter, under three wind speeds $(0,11$ and $14 \mathrm{~m} / \mathrm{s})$ and three rainfall intensities $(60$, 80 and $100 \mathrm{~mm} / \mathrm{h}$ ). The results showed that the sediment yield was positively correlated with wind speed and rainfall intensity $(P<0.01)$. Wind erosion exacerbated water erosion and increased sediment yield by $7.25 \%-38.97 \%$ relative to the absence of wind erosion. Wind erosion changed the sediment particle distribution by influencing the micro-topography of the sloping land surface. The clay, silt and sand contents of eroded sediment were also positively correlated with wind speed and rainfall intensity $(P<0.01)$. Wind erosion increased clay and silt contents by $0.35 \%-19.60 \%$ and $5.80 \%-21.10 \%$, respectively, and decreased sand content by $2.40 \%-8.33 \%$, relative to the absence of wind erosion. The effect of wind erosion on sediment particles became weaker with increasing rainfall intensities, which was consistent with the variation in sediment yield. However, particle-size distribution was not closely correlated with sediment yield $(P>0.05)$. The fractal dimension of the sediment particles was significantly different under different intensities of water erosion $(P<0.05)$, but no significant difference was found under wind and water erosion. The findings reported in this study implicated that both water and wind erosion should be controlled to reduce their intensifying effects, and the controlling of wind erosion could significantly reduce water erosion in this wind-water erosion crisscross region.
\end{abstract}

Keywords: sediment yield; particle-size distribution; fractal dimension; wind and water erosion

Citation: TUO Dengfeng, XU Mingxiang, ZHAO Yunge, GAO Liqian. 2015. Interactions between wind and water erosion change sediment yield and particle distribution under simulated conditions. Journal of Arid Land, 7(5): 590-598. doi: 10.1007/s40333-015-0128-7

Wind and water are two dominant agents of erosion that lead to soil loss in arid and semi-arid regions. Wind erosion is recognized as a dynamic process that selectively removes the finer particles of soil (Lü and Dong, 2006; Zhao et al., 2006; Dong and Qian, 2007), resulting in important ecological and environmental problems such as dust storms and reduced visibility (Tang, 2000; Visser et al., 2004). Water erosion is comprised of splash and flow detachment, transport by overland flow and deposition of soil materials (Lssa et al., 2006). Both types of erosion can enrich the amount of fine particles (Catroux and Schnizer, 1987) and nutrients in exported sediments (Alberts et al., 1983). The processes of wind and water erosion, however, rarely operate independently in landscapes but substantially interact.

*Corresponding author: XU Mingxiang (E-mail: xumx@nwsuaf.edu.cn) 
Both wind and water erosion are possible for severe land degradation in an area of over $17.8 \times 10^{4} \mathrm{~km}^{2}$ on the Loess Plateau of China, which is known as a wind-water erosion crisscross region (Tang, 2000; Yang et al., 2013). In this region, aeolian action is dominant during winters and springs, and fluvial action is dominant during rainy summers and autumns $(\mathrm{Xu}$, 1998). Wind and water erosion are mutually affected (Uri, 2001). For example, coarse particles transported to slopes and channels by wind erosion provide the material basis for the action of water erosion, and water erosion force reshapes the landforms sculpted by wind erosion (Song et al., 2006). Moreover, the transport of soil particles by one type of erosion can be accelerated by the other type (Pedersen and Hasholt, 1995; Erpul et al., 2002). Wind erosion can lead to the loss of fine soil particles and an increase in soil roughness (Zhao et al., 2006; Ferreira et al., 2011), which can turn slow overland flows into supercritical flows that may increase the potential for scouring by water (Romkens et al., 2001; Gomez and Nearing, 2005).

Wind and water erosion provide many interactions between the two systems that have important influences on landforming processes (Langford, 1989; Sweeney and Loope, 2001; Gao et al., 2002; Joanna and Lan, 2002). The transport of wind-driven sediment can degrade streams, lakes and estuaries (Pieri et al., 2009) and have an impact on fluvial features. In Sahara, the sand mainly originated from fluvial processes, but the fluvially-deposited sand was subsequently reshaped by aeolian activity into dunes and sheets during periods of drier climates (Farouk et al., 2000). Bullard and Livingstone (2000) also reported that fluvial and coastal processes interact in estuarine environments. Aeolian processes are not restricted to dryland environments. They also operate in coastal and periglacial landscapes.

Previous studies on the interactions between wind and water erosion have focused on the simultaneous occurrence of rain and wind, i.e. wind-driven raindrops (de Lima et al., 1992; Visser et al., 2004). Wind-driven rain (WDR) is rain that is given a horizontal velocity component by the wind and that falls obliquely (Blocken and Carmeliet, 2004). The WDR effect refers to the redistribution of rainfall over micro-scale topography due to the existence of local perturbed wind-flow patterns (Blocken et al., 2006). Sediment yield and the characteristics of sediment particles under alternating wind and water erosion, however, are poorly understood. A fuller understanding of their interactions is particularly needed because of their importance in understanding the response of soil quality and the impact of the environmental stresses from alternating wind and water erosion.

The sediment size distribution may govern the actual behavior of sediment transport (Slattery and Burt, 1997; Wang et al., 2014). Shi et al. (2012a, b) found that a better understanding of sediment sorting will improve our comprehension on erosion and sedimentation processes. Fractal dimension of soil particles has been possible to characterize soil particle-size distribution, and previous researches have shown that it is a useful parameter for monitoring soil degradation (Su et al., 2004) and quantifying the structure (Perrier et al., 1999) and physical properties of soil (Perfect and Kay, 1995). Many factors affect fractal dimension, such as erosion, land use patterns (Chen and Zhou, 2013) and plant communities (Xu et al., 2013). Zhang et al. (2011) conducted a field experiment in the Loess Plateau of Northwest China to determine the effect of water erosion on the fractal dimension of particle-size distribution. They found that soils with higher silt and clay contents and lower sand contents have higher values of fractal dimension. Fine soil particles are readily transported by wind erosion. Water erosion leads to the enrichment of fine particles in sediments (Wan and El-Swaify, 1998). Both erosion processes can cause changes in sediment particle-size distribution. However, limited information is available on the fractal characteristics of sediment under alternating wind and water erosion.

Rain simulators are commonly used to quantify water erosion, and wind tunnels are usually applied to determine wind erosion (Breshears et al., 2003). We therefore conducted a controlled experiment that combined a wind tunnel with simulated rainfall. The objectives of this study were to: 1) obtain detailed information on the effects of wind and water erosion on sediment yield, particle-size distribution and the fractal dimension of sediment, and 2) understand the key factors influencing sediment yield and associated particle characteristics under wind and water erosion. 


\section{Materials and methods}

\subsection{Experimental materials}

The experiment was conducted in a simulation hall at the State Key Laboratory of Soil Erosion and Dryland Farming on the Loess Plateau, Northwest A\&F University, China. The experimental facilities included a wind-tunnel simulator and a rainfall simulator. The wind tunnel had a total length of $24 \mathrm{~m}$, including fan $(4 \mathrm{~m})$, regulation $(1.5 \mathrm{~m})$, rectification $(10 \mathrm{~m})$, test $(1.28 \mathrm{~m})$, sand-collection $(3.02 \mathrm{~m})$ and diversion (4.2 m) sections (Fig. 1). The $1.0 \mathrm{~m} \times 1.2 \mathrm{~m}$ cross-sectional area can produce free turbulent airflow and a stable airflow field. The uniformity of airflow velocity is $>99 \%$, and the static pressure gradient in the axial direction is $<0.005$. Wind speed could change continuously from 0 to $15 \mathrm{~m} / \mathrm{s}$ via the control panel. A vane anemometer, installed $0.2 \mathrm{~m}$ close to the test section and $0.2 \mathrm{~m}$ above the tunnel floor, accurately $( \pm 0.2 \mathrm{~m} / \mathrm{s})$ adjusted the wind speed. The diversion section evacuated the airflow to maintain a clean laboratory environment. The wind-driven sediment was trapped in the deposition chamber at the end of the wind tunnel with a capture efficiency of $90 \%$ (Wang et al., 2014).

The nozzle height of the rainfall simulator was 16 $\mathrm{m}$. The drop size distribution ranged from 0.6 to 3.0 $\mathrm{mm}$ and the rain heterogeneity was greater than $85 \%$. Rainfall intensity was accurately $( \pm 2.7 \mathrm{~mm} / \mathrm{h})$ adjusted by controlling the aperture of the nozzle and the water pressure. Experimental boxes for wind and water ero- sion were constructed with a movable dual-function steel tank (110 cm long $\times 70 \mathrm{~cm}$ wide $\times 35 \mathrm{~cm}$ deep).

The sandy loam used for the experiment was collected from the surface $(0-20 \mathrm{~cm}$ depth) of a natural grassland in Wuqi county $\left(36^{\circ} 58^{\prime} 32^{\prime \prime} \mathrm{N}, 107^{\circ} 50^{\prime} 52^{\prime \prime} \mathrm{E}\right)$ in the northern part of the Loess Plateau, China. The soil was the primary eroded soil in this wind-water erosion crisscross region. The soil properties are listed in Table 1 (data were measured from the methods in Part 1.3).

\subsection{Experimental design}

In the study area, wind erosion occurs mainly during winter and spring; while rain falls mostly occur during summer, typically in high-intensity and short-duration rainstorms (Zhang et al., 2011). The experiment was conducted with wind erosion firstly and water erosion thereafter, under three wind speeds $(0,11$ and $14 \mathrm{~m} / \mathrm{s})$ and three rainfall intensities $(60,80$ and $100 \mathrm{~mm} / \mathrm{h})$. The wind speed of $14 \mathrm{~m} / \mathrm{s}$ approached the maximum monthly average wind speed (Wang et al., 2014). The chosen rainfall intensities are representative of low-, medium- and high-intensity rainstorms. Both are typical of intense storms in the study area that is dominated by monsoon climate conditions (Tang, 1990).

Soil samples were air-dried to a moisture content of approximately $1.3 \%$, mixed well and then packed into the soil box in 5-cm layers at an average bulk density of $1.30 \mathrm{~g} / \mathrm{cm}^{3}$. Each layer was roughened by a small rake to reduce the discontinuity between layers. The total layers in every box were seven. Once the box was prepared, it was pushed into the wind tunnel and

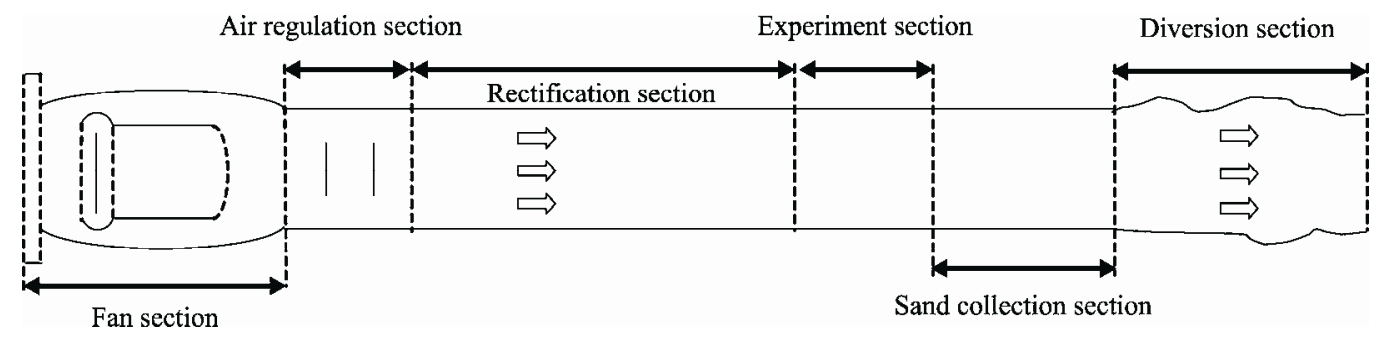

Fig. 1 Diagram of the wind tunnel structure

Table 1 Properties of the experimental soil

\begin{tabular}{|c|c|c|c|c|c|c|c|}
\hline \multicolumn{2}{|c|}{ Nutrients content $(\mathrm{g} / \mathrm{kg})$} & \multirow{2}{*}{$\begin{array}{c}\text { Average } \\
\text { particle size } \\
(\mathrm{mm})\end{array}$} & \multicolumn{2}{|c|}{ Aggregate stability } & \multicolumn{3}{|c|}{ Particle-size distribution (\%) } \\
\hline $\mathrm{OM}$ & $\mathrm{TN}$ & & WSA $(\%)$ & MWD (mm) & $<0.002 \mathrm{~mm}$ & $0.002-0.020 \mathrm{~mm}$ & $0.020-2.000 \mathrm{~mm}$ \\
\hline 12.37 & 0.65 & 0.026 & 10.09 & 0.36 & 12.68 & 19.12 & 68.20 \\
\hline
\end{tabular}

Notes: OM, organic matter; TN, total nitrogen; WSA, water-stable aggregates ( $>0.25 \mathrm{~mm})$; MWD, mean weighted diameter. 
the soil surface was aligned exactly paralleled to the floor of the test section. Wind erosion was simulated for $20 \mathrm{~min}$, after which the experimental box was removed and packed with a rainfall baffle and a plot outlet that were used for rainfall at a slope of $15^{\circ}$. This slope was chosen because lands with slopes between $10^{\circ}$ and $20^{\circ}$ were widely used for cropping in this region (Shi et al., 2012b). The duration of each rainstorm was $1 \mathrm{~h}$. The runoff was collected in a plastic bucket at the plot outlet, and allowed to stand $20 \mathrm{~h}$ to separate the sediment from the water. The water was discarded, and then the sediment samples were dried in a forced-air oven at $105^{\circ} \mathrm{C}$ until constant mass was achieved, and then weighed. Thereafter, the eroded sediment was transported in plastic bags to the laboratory for particle distribution measurement. All treatments were performed in triplicate. The sediment particles were classified as clay $(<0.002 \mathrm{~mm})$, silt $(0.002-0.020 \mathrm{~mm})$ and sand $(0.020-2.000 \mathrm{~mm})$ based on USA classification (Zhang et al., 2011).

\subsection{Measurement}

The measurement of the dispersed-particle distribution was performed using a laser-diffraction method (Mastersizer 2000, Malvern, UK). Organic matter was determined using the Walkleye Black method (Nelson and Sommers, 1982). Total nitrogen was determined by the Kjeldahl method (Bremner and Mulvaney, 1982). A wet-sieving method was used to determine the size distribution of soil aggregates. The soil mean weight diameter (MWD) was calculated as (Kihara et al., 2011):

$$
\mathrm{MWD}=\sum_{i=1}^{n} \overline{R_{i}} w_{i} .
$$

Where $\overline{R_{i}}$ is the average diameter of the openings of two consecutive sieves, and $w_{i}$ is the weight ratio of the aggregates retained by sieve $i$. The volume-based fractal dimension (D) of sediment was determined using the following formula (Zhang et al., 2011):

$$
V\left(r<R_{i}\right) / V_{\mathrm{T}}=\left(R_{i} / R_{\max }\right)^{3-\mathrm{D}} .
$$

Where $r$ is particle size, $R_{i}$ is the particle size of the $i^{\text {th }}$ size class, $V\left(r<R_{i}\right)$ is the cumulative volume of particles sized less than $R_{i}, V_{\mathrm{T}}$ is the total volume of particles, and $R_{\max }$ is the diameter of the largest particle.

\subsection{Statistical analysis}

One-way ANOVA was used to examine the effects of wind erosion on sediment yield and particle-size distribution and of water erosion on the fractal dimension of sediment. When treatments were significantly different $(P<0.05)$, Fisher's least significant difference test was used to compare treatment means. Regression analyses and two-way ANOVA were performed to verify the effects of the interactions between wind speed and rain intensity on sediment yield and particle-size distribution. All statistical analyses were performed using SPSS 18.0.

\section{Results}

\subsection{Effects of wind and water erosion on sediment yield}

The average sediment yield in our study for water erosion from simulated rainfalls of 60,80 and $100 \mathrm{~mm} / \mathrm{h}$ were $109.23,193.20$ and $302.90 \mathrm{~g}$, respectively. The average sediment yield from rainfall of $100 \mathrm{~mm} / \mathrm{h}$ was approximately three-fold higher than that from $60 \mathrm{~mm} / \mathrm{h}$ due to the higher erosivity of the higher intensity rainfall (Fig. 2a). These results were in agreement with many studies on the impact of rainfall on soil erosion (Kleinman et al., 2006).

Mean sediment yields across a range of wind speeds and rainfall intensities ranged from 109.23 to $373.15 \mathrm{~g}$. Wind speed had a significant effect on sediment yield under water erosion at all rainfall intensities $(P<0.05)$. Sediment yield from water erosion was higher at higher wind speeds, increased by $7.25 \%-38.97 \%$ with wind erosion relative to yields with no wind erosion. Additionally, sediment yields with wind erosion increased by $27.90 \%-38.97 \%$ at the low rainfall intensity of 60 $\mathrm{mm} / \mathrm{h}$, as compared to no wind erosion. In contrast, the sediment yields with wind erosion increased by $7.25 \%-23.19 \%$ at the high rainfall intensity of 100 $\mathrm{mm} / \mathrm{h}$. These results demonstrated that the effect of wind erosion on sediment yield decreased with increasing rainfall intensities across the interaction effects exhibited between them.

\subsection{Effects of wind and water erosion on parti- cle-size distribution}

Wind erosion could induce an accumulation of clay and silt in exported sediment under conditions of water erosion, with an increase of $0.35 \%-19.60 \%$ in clay content and $5.80 \%-21.10 \%$ in silt content, relative to 

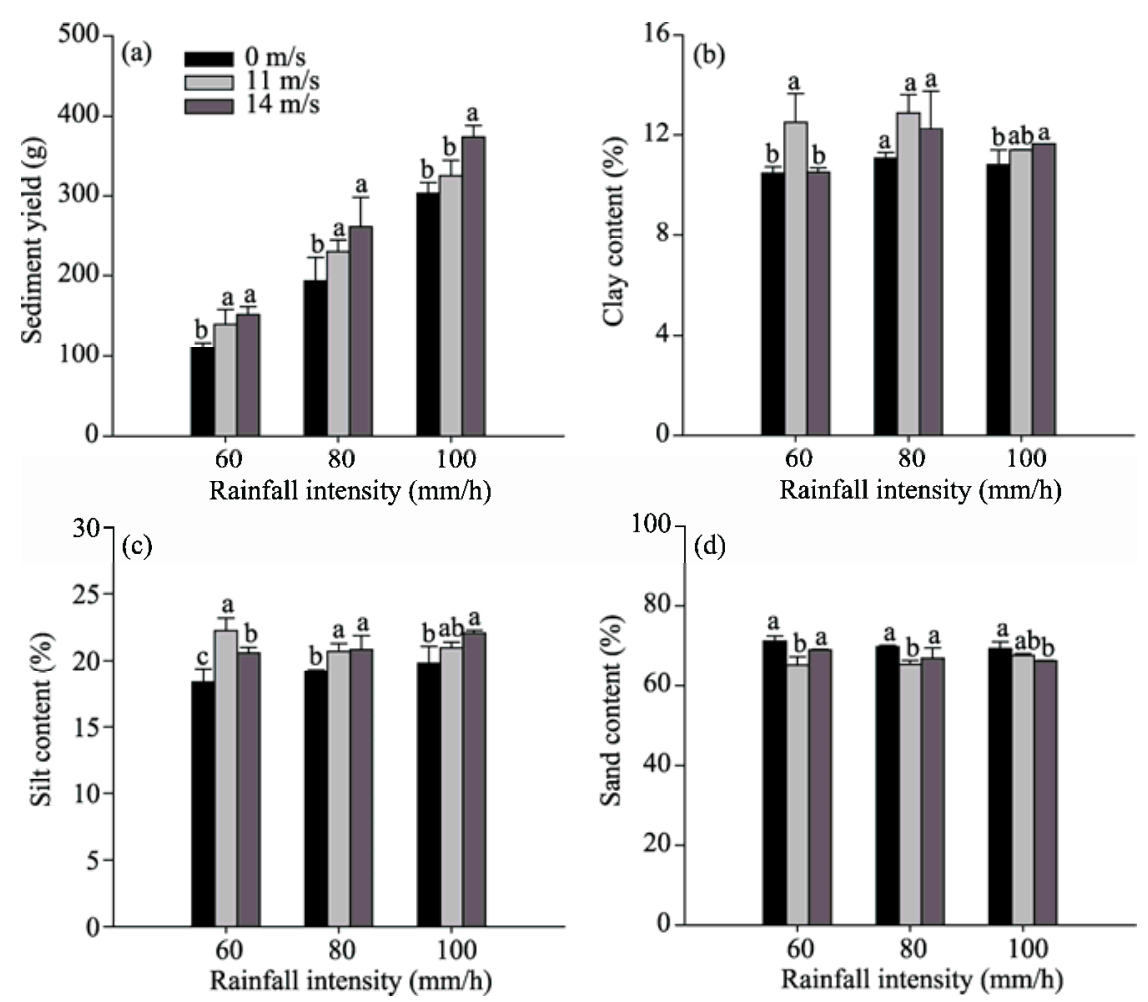

Fig. 2 Sediment yield (a) and particle-size distribution (b, c, d) under various wind speeds and rainfall intensities. Different letters in the same rainfall intensity are significantly different at $P<0.05$ level.

the contents without wind erosion (Figs. 2b and c). Accordingly, $2.40 \%-8.33 \%$ less sand was observed in the sediment at rainfall intensities of 60,80 and $100 \mathrm{~mm} / \mathrm{h}$ and wind speeds of 11 and $14 \mathrm{~m} / \mathrm{s}$ (Fig. 2d). The effect of wind erosion on sediment particles, however, became weaker with increasing rainfall intensities. The sediment at a rainfall intensity of $60 \mathrm{~mm} / \mathrm{h}$ and wind speeds of 11 and $14 \mathrm{~m} / \mathrm{s}$ had higher clay and silt contents relative to those with no wind erosion, with increases of $0.35 \%-19.60 \%$ in clay content and $12.03 \%-21.10 \%$ in silt content. In contrast, the sediment at a rainfall intensity of $100 \mathrm{~mm} / \mathrm{h}$ and the same conditions of wind erosion had lower clay and silt contents, with increases of $5.44 \%-7.66 \%$ in clay content and $5.80 \%-11.27 \%$ in silt content.

As an additional parameter to describe sediment properties, the fractal dimension (D) of particle-size distribution reflects selective soil erosion based on the distribution of eroded particles in the sediment. As shown in Table 2, the $\mathrm{D}$ values ranged from 1.97 to 2.01 under water erosion at rainfall intensities of 60 , 80 and $100 \mathrm{~mm} / \mathrm{h}$ and wind erosion at wind speeds of 11 and $14 \mathrm{~m} / \mathrm{s}$. Dissimilar to the changes in clay and silt contents, the D values with wind erosion were not significantly different under water erosion relative to those without wind erosion.

\subsection{Correlations among sediment yield, particle size and erosion factors}

Wind speed had a significant effect on sediment yield and the characteristics of the sediment particles $(P<0.01$; Table 3$)$. Rainfall intensity had a significant effect on sediment yield, clay particles and the fractal dimension $(P<0.05)$. The interactions between wind speed and rainfall intensity had significant effects on silt and sand particles $(P<0.05)$ but no significant effects on sediment yield and fractal dimension $(P>$ $0.05)$. Moreover, sediment yield and fractal dimension exhibited significant differences under separate wind and water erosion $(P<0.05)$ but not under alternating wind and water erosion $(P>0.05)$.

The relationships between sediment yield and associated particle characteristics with wind and water erosion are shown in Table 4. Sediment yield and sediment particles were positively correlated with wind speed and rainfall intensity; linear functions best fitted their relationships $(P<0.01)$. 
Table 2 Distribution and fractal dimension of sediment particles under different rainfall intensities and wind speeds

\begin{tabular}{|c|c|c|c|c|c|c|c|}
\hline \multirow{2}{*}{ Rainfall intensity $(\mathrm{mm} / \mathrm{h})$} & \multirow{2}{*}{$\begin{array}{l}\text { Wind speed } \\
(\mathrm{m} / \mathrm{s})\end{array}$} & \multicolumn{5}{|c|}{ Particle-size distribution (\%) } & \multirow{2}{*}{ Fractal dimension } \\
\hline & & $<0.002 \mathrm{~mm}$ & $0.002-0.01 \mathrm{~mm}$ & $0.01-0.05 \mathrm{~mm}$ & $0.05-0.1 \mathrm{~mm}$ & $0.1-1 \mathrm{~mm}$ & \\
\hline \multirow[t]{3}{*}{60} & 0 & $10.47^{\mathrm{b}}$ & $6.97^{\mathrm{c}}$ & $50.25^{\mathrm{a}}$ & $25.81^{\mathrm{a}}$ & $6.50^{\mathrm{a}}$ & $1.98^{\mathrm{a}}$ \\
\hline & 11 & $12.52^{\mathrm{a}}$ & $8.68^{\mathrm{a}}$ & $51.46^{\mathrm{a}}$ & $22.48^{\mathrm{c}}$ & $4.86^{\mathrm{a}}$ & $2.00^{\mathrm{a}}$ \\
\hline & 14 & $10.51^{\mathrm{b}}$ & $7.54^{\mathrm{b}}$ & $52.07^{\mathrm{a}}$ & $24.25^{\mathrm{b}}$ & $5.63^{\mathrm{ab}}$ & $1.99^{\mathrm{a}}$ \\
\hline \multirow[t]{3}{*}{80} & 0 & $11.06^{\mathrm{a}}$ & $7.21^{\mathrm{b}}$ & $50.97^{\mathrm{a}}$ & $24.79^{\mathrm{a}}$ & $5.97^{\mathrm{a}}$ & $1.98^{\mathrm{a}}$ \\
\hline & 11 & $12.90^{\mathrm{a}}$ & $8.42^{\mathrm{a}}$ & $50.85^{\mathrm{a}}$ & $22.39^{\mathrm{b}}$ & $5.43^{\mathrm{a}}$ & $2.01^{\mathrm{a}}$ \\
\hline & 14 & $12.25^{\mathrm{a}}$ & $7.98^{\mathrm{ab}}$ & $51.15^{\mathrm{a}}$ & $23.29^{\mathrm{ab}}$ & $5.33^{\mathrm{a}}$ & $2.00^{\mathrm{a}}$ \\
\hline \multirow[t]{3}{*}{100} & 0 & $10.80^{\mathrm{b}}$ & $7.25^{\mathrm{b}}$ & $51.70^{\mathrm{a}}$ & $24.15^{\mathrm{a}}$ & $5.74^{\mathrm{a}}$ & $1.98^{\mathrm{a}}$ \\
\hline & 11 & $11.39^{\mathrm{ab}}$ & $7.73^{\mathrm{ab}}$ & $52.15^{\mathrm{a}}$ & $23.38^{\mathrm{ab}}$ & $5.35^{\mathrm{a}}$ & $1.99^{\mathrm{a}}$ \\
\hline & 14 & $11.63^{\mathrm{a}}$ & $8.17^{\mathrm{a}}$ & $52.45^{\mathrm{a}}$ & $22.71^{\mathrm{b}}$ & $5.04^{\mathrm{a}}$ & $1.99^{\mathrm{a}}$ \\
\hline
\end{tabular}

Note: values followed by different letters with columns in the same rainfall intensity are significantly different at $P<0.05$ level.

Table 3 Significance levels of the correlations among wind speed, rainfall intensity and their interactions on sediment yield and sediment particles

\begin{tabular}{lccc}
\hline & Wind speed (WS) & Rainfall intensity (RI) & Interaction (WS $\times$ RI) \\
\hline Sediment yield & $0.002^{* *}$ & $0.000^{* *}$ & 0.846 \\
Clay $(<0.002 \mathrm{~mm})$ & $0.001^{* *}$ & $0.030^{*}$ & 0.109 \\
Silt $(0.002-0.02 \mathrm{~mm})$ & $0.000^{* *}$ & 0.334 & $0.003^{* *}$ \\
Sand $(0.02-2 \mathrm{~mm})$ & $0.000^{* *}$ & 0.260 & $0.046^{*}$ \\
Fractal dimension & $0.001^{* *}$ & $0.037^{*}$ & 0.249 \\
\hline
\end{tabular}

Note: ${ }^{*}$, correlation is significant at $P<0.05$ level; ${ }^{* *}$, correlation is significant at $P<0.01$ level.

Table 4 Regression analysis of sediment properties with wind speed and rainfall intensity

\begin{tabular}{lc}
\hline & Regression equation \\
\hline Sediment yield & $Y_{a}=-200.622+3.871 W S+5.001 R I\left(R^{2}=0.902, n=27, P<0.01\right)$ \\
Clay $(<0.002 \mathrm{~mm})$ & $Y_{b}=-23.544+0.613 W S+0.566 R I\left(R^{2}=0.842, n=27, P<0.01\right)$ \\
Silt $(0.002-0.02 \mathrm{~mm})$ & $Y_{b}=-46.429+1.152 W S+1.063 R I\left(R^{2}=0.897, n=27, P<0.01\right)$ \\
Sand $(0.02-2 \mathrm{~mm})$ & $Y_{b}=-130.569+2.112 W S+3.370 R I\left(R^{2}=0.914, n=27, P<0.01\right)$ \\
\hline
\end{tabular}

Note: $Y_{a}, Y_{b}, W S$ and $R I$ denote the amount of sediments $(\mathrm{g})$, sediment particles $(\mathrm{g})$, wind speed $(\mathrm{m} / \mathrm{s})$ and rainfall intensity (mm/h), respectively; $R^{2}, n$ and $P$ are coefficients of determination, sample numbers and significance, respectively.

\section{Discussion}

\subsection{Effects of wind and water erosion on sediment yield}

In this study, the effect of wind and water erosion on sediments was different from that of the separate erosion events. First, wind erosion was sufficiently strong to increase soil erodibility by removing fine particles and leaving behind coarse particles (Gomes et al., 2003; Song et al., 2006; Zhao et al., 2006). Second, fringes and grooves on hill slopes were created by the shearing force of wind erosion. Eventually, these changes of slope micro-topography could increase soil surface roughness (i.e. linear rills oriented from upslope to downslope), which can convert a slow flow of rainwater into a supercritical flow that may increase the potential for scouring (Romkens et al., 2001; Gomez and Nearing, 2005). The current study demonstrated that wind erosion clearly had the capacity to intensify water erosion (Fig. 2a). Our results were consistent with the findings by $\mathrm{Xu}$ (2000), who reported that wind erosion treatments increased the erosion rate in the wind-water crisscross region. However, the effects of wind erosion on sediment were weakened by high rainfall intensities, which produced high sediment yields but reduced the influence of wind erosion. These results demonstrated that the sediment yield was closely related to wind erosion, and it was meanwhile influenced by changed intensities of water erosion. 


\subsection{Effects of wind and water erosion on parti- cle-size distribution}

The characteristics of rainfall storm events determine the erosive action of raindrops, while soil properties and surface conditions affect the detachability and transportability of particles (Sharma, 1996). In this study, the soils used for water erosion were not original, since soil structure has been destroyed by wind erosion (Ekhtesasi and Sepehr, 2009). During the water erosion process, sediment was enriched with finer particles. The aggregate breakdown was likely to be a major factor affecting size distribution (Shi et al., 2012a; Wang et al., 2014). Therefore, the transportation of sediment particles by wind and water erosion were closely related (Xu, 1998). The present study demonstrated that wind erosion could induce an accumulation of clay and silt in exported sediment under conditions of water erosion (Figs. $2 b$ and c). This could be attributed to either structural breakdown by wind, uneven or selective transport of different size classes due to raindrop impacts, or a combination of these effects. Xu (2005) made a similar observation that wind erosion supplied the coarse particles, and alternating wind and water erosion supplied the finer particles, which helped to form hyper-concentrated flows.

By using fractal dimension (D) to estimate the relationship between sediment particles and erosion conditions, Table 3 clearly showed no significant differences in $\mathrm{D}$ values across all wind speeds and rainfall intensities. The results indicated that fractal dimension couldn't be used to characterize sediment particles under alternating wind and water erosion, which was inconsistent with the findings by Zhang et al. (2011), who reported higher silt and clay contents and lower sand contents in exported sediment with higher values of $\mathrm{D}$.
In general, smaller and less dense particles are preferentially eroded than larger and denser ones (Zhang et al., 2011). The present study also showed that rainfall intensity differentially influenced the particle-size distribution of sediment. The effect of wind erosion on particle-size distribution of eroded sediment became weaker with increasing rainfall intensities. This change could be ascribed to the much higher contribution of intense rain to sediment content. Intense rain made a more obvious soil erosion change owing to its higher erosivity, thus reducing the particle size selectivity of eroded sediment.

\subsection{Correlations among sediment yield, particle size and fractal dimension}

Sediment yield, clay and silt content under water erosion at various rainfall intensities could be increased by wind erosion, and the extent of the influence decreased with increasing rainfall intensities (Fig. 2). This finding implied that both water and wind erosion should be controlled to reduce the intensifying effects of alternating water and wind erosion in the study area. The fractal dimension was positively correlated with particle-size distribution $(P<0.01)$, whereas sediment yield was not closely correlated with particle-size distribution $(P>0.05$; Table 5$)$, which was perhaps due to the differential influence of wind erosion. On the one hand, wind erosion was recognized as a dynamic process that induces slope erosion fringes and grooves (Gomes et al., 2003; Ekhtesasi and Sepehr, 2009), which could increase the potential for scouring action (Romkens et al., 2001; Gomez and Nearing, 2005) and thereby lead to increasing sediment yield (Fig. 2a). On the other hand, wind erosion could directly affect aggregate degradation in the original soil, and further induce an accumulation of clay and silt in the sediment (Figs. 2b and c). Thus, the differences in sediment yield and particle-size distribution had different causes.

Table 5 Correlations among sediment properties

\begin{tabular}{lccccc}
\hline & Sediment yield & Clay content & Silt content & Sand content & Fractal dimension \\
\hline Sediment yield & 1.000 & 0.228 & 0.354 & -0.328 & 0.237 \\
Clay content & & 1.000 & $0.733^{* *}$ & $-0.908^{* *}$ & $0.981^{* *}$ \\
Silt content & & 1.000 & $-0.950^{* *}$ & $0.720^{* *}$ \\
Sand content & & & 1.000 & $-0.891^{* *}$ \\
Fractal dimension & & & & 1.000 \\
\hline
\end{tabular}

Note: ${ }^{*}$ and $^{* *}$ indicate significant correlations at $P<0.05$ and $P<0.01$ levels, respectively. 


\section{Conclusions}

The effects of wind and water erosion on sediments differ from those of wind or water erosion alone. The sediment yield under water erosion at different rainfall intensities could be promoted by $7.25 \%-38.97 \%$ with the presence of wind erosion compared to with the absence of wind erosion. Wind erosion changed the sediment particle distribution of water erosion. It increased clay and silt contents by $0.35 \%-19.60 \%$ and $5.80 \%-21.10 \%$, respectively, and meanwhile decreased sand content by $2.40 \%-8.33 \%$, relative to the absence of wind erosion. The effect of wind erosion on sediment particles became weaker with increasing rainfall intensities. Sediment yield and sediment particles were positively correlated with wind speed and rainfall intensity $(P<0.01)$, which was, meanwhile, influenced by changed intensities of wind and water erosion. The results implicated that both water and wind erosion should be controlled to reduce the intensifying effects of alternating water and wind erosion, however the controlling of wind erosion could significantly reduce water erosion in the wind-water erosion crisscross region. Wind erosion-influenced sediment yield and particle-size distribution of eroded sediment were recommended to be considered when predicting erosion in regions of alternating wind-water forces.

\section{Acknowledgments}

This research was financially supported by the Special Program for Basic Research of the Ministry of Science and Technology, China (2014FY210100), the National Natural Science Foundation of China (41171422, 41271298) and the West Light Foundation of the Chinese Academy of Sciences.

\section{References}

Alberts E E, Wendt R C, Piest R F. 1983. Physical and chemical properties of eroded soil aggregates. Transactions of the Asae, 26: $465-471$.

Blocken B, Carmeliet J. 2004. A review of wind-driven rain research in building science. Journal of Wind Engineering and Industrial Aerodynamics, 92(13): 1079-1130.

Blocken B, Poesen J, Carmeliet J. 2006. Impact of wind on the spatial distribution of rain over micro-scale topography-numerical modelling and experimental verification. Hydrological Processes, 20: 345-368.
Bremner J M, Mulvaney C S. 1982. Nitrogen-total. Agronomy monograph 9. In: Methods of Soil Analysis, Part 2, Chemical and Microbial Properties. Madison, Wisconsin: Agronomy Society of America, 595-624.

Breshears D D, Whicker J J, Johansen M P, et al. 2003. Wind and water erosion and transport in semi-arid shrubland, grassland and forest ecosystems: quantifying dominance of horizontal wind-driven transport. Earth Surface Processes and Landforms, 28: 1189-1209.

Bullard J E, Livingstone I. 2002. Interactions between aeolian and fluvial systems in dryland environments. Area, 34: 8-16.

Catroux G, Schnitzer M. 1987. Chemical, spec-troscopic, and biological characteristics of the organic matter in particle size fractions separated from an Aquoll. Soil Science Society of America Journal, 51: 1200-1207.

Chen X Y, Zhou J. 2013. Volume-based soil particle fractal relation with soil erodibility in a small watershed of purple soil. Environmental Earth Sciences, 70(4): 1735-1746.

de Lima J L M P, van Dijck P M, Spaan W P. 1992. Splash-saltation transport under wind-driven rain. Soil Technology, 5: 151-166.

Dong Z B, Qian G Q. 2007. Characterizing the height profile of the flux of wind-eroded sediment. Environmental Geology, 51: 835-845.

Ekhtesasi M R, Sepehr A. 2009. Investigation of wind erosion process for estimation, prevention, and control of DSS in Yazd-Ardakan plain. Environmental Monitoring and Assessment, 159: 267-280.

Erpul G, Norton L D, Gabriels D. 2002. Raindrop-induced and wind-driven soil particle transport. Catena, 47: 227-243.

Farouk E B, Maingue M, Robinson C. 2000. Fluvio-aeolian dynamics in the north-eastern Sahara: the relationship between fluvial/aeolian systems and ground-water concentration. Journal of Arid Environments, 44: 173-183.

Ferreira A D, Farimani A, Sousa A C M. 2011. Numerical and experimental analysis of wind erosion on a sinusoidal pile. Environmental Fluid Mechanics, 11: 167-181.

Gao Q, Ci L, Yu M. 2002. Modeling wind and water erosion in northern China under climate and land use changes. Journal of Soil and Water Conservation, 57: 46-55.

Gomes L, Arrue J L, Lopez M V, et al. 2003. Wind erosion in a semiarid agricultural area of Spain: the welsons project. Catena, 52: 235-256.

Gomez J A, Nearing M A. 2005. Runoff and sediment losses from rough and smooth soil surfaces in a laboratory experiment. Catena, 59: 253-266.

Joanna E B, Lan L. 2002. Interactions between aeolian and fluvial systems in dryland environments. Area, 34: 8-16.

Kihara J, Bationo A, Mugendi D N, et al. 2011. Conservation tillage, local organic resources and nitrogen fertilizer combinations affect maize productivity, soil structure and nutrient balances in semi-arid Kenya. Nutrient Cycling in Agroecosystems, 90(2): 213-225.

Kleinman P J, Srinivasan M S, Dell C J, et al. 2006. Role of rainfall intensity and hydrology in nutrient transport via surface runoff. Journal of Environmental Quality, 35: 1248-1259.

Langford R P. 1989. Fluvial-aeolian interactions: Part I. modern systems. Sedimentology, 36: 1023-1035.

Lssa O M, Le Bissonnais Y, Planchon O, et al. 2006. Soil detachment and transport on field-and laboratory-scale interrill areas: erosion 
processes and the size-selectivity of eroded sediment. Earth Surface Processes and Landforms, 31: 929-939.

Lü P, Dong Z B. 2006. Wind tunnel experiments on the turbulent transmission over the near surface layer of different surfaces. Environmental Geology, 50: 983-988.

Nelson D W, Sommers L E. 1982. Total carbon, organic carbon, and organic matter. Agronomy monograph 9. In: Methods of Soil Analysis, Part 2, Chemical and Microbial Properties. Madison, Wisconsin: Agronomy Society of America, 539-552.

Pedersen H S, Hasholt B. 1995. Influence of wind speed on rainsplash erosion. Catena, 24: 39-54.

Perfect E, Kay B D. 1995. Applications of fractals in soil and tillage research: a review. Soil and Tillage Research, 36: 1-20.

Perrier E, Bird N, Rieu M. 1999. Generalizing the fractal model of soil structure: the pore-solid fractal approach. Geoderma, 88: 137-164.

Pieri L, Bittelli M, Hanuskova M, et al. 2009. Characteristics of eroded sediments from soil under wheat and maize in the North Italian Apennines. Geoderma, 154: 20-29.

Romkens M J M, Helming K, Prasad S N. 2001. Soil erosion under different rainfall intensities, surface roughness, and soil water regimes. Catena, 46: 103-123.

Sharma P P. 1996. Interrill erosion. In: Soil Erosion, Conservation, and Rehabilitation. New York: Marcel Dekker, 125-152.

Shi Z H, Fang N F, Wu F Z, et al. 2012a. Soil erosion processes and sediment sorting associated with transport mechanisms on steep slopes. Journal of Hydrology, 454-455: 123-130.

Shi Z H, Yue B J, Wang L, et al. 2012b. Effects of mulch cover rate on interrill erosion processes and the size selectivity of eroded sediment on steep slopes. Soil Science Society of America Journal, 77: 257-267.

Slattery M C, Burt T P. 1997. Particle size characteristics of suspended sediment in hillslope runoff and stream flow. Earth Surface Process and Landforms, 22: 705-719.

Song Y, Liu L Y, Yan P. 2006. A review on complex erosion by wind and water research. Journal of Geographical Sciences, 16: 231-241.

Su Y Z, Zhao H L, Zhao W Z, et al. 2004. Fractal features of soil particle-size distribution and the implication for indicating desertification. Geoderma, 122: 43-49.

Sweeney M R, Loope D B. 2001. Holocene dunesourced alluvial fans in the Nebraska Sand Hills. Geomorphology, 38: 31-46.

Tang K L. 2000. Importance and urgency of harnessing the interlocked area with both water and wind erosion in the Loess Plateau. Soil and Water Conservation in China, 11: 11-12, 17. (in Chinese)

Tang K L, Hou Q C, Wang B K, et al. 1993. The environment background and administration way of wind-water erosion crisscross region and Shenmu experimental area on the Loess Plateau. Research of Soil and Water Conservation, 18: 1-15. (in Chinese)

Uri N D. 2001. The environmental implications of soil erosion in the United States. Environmental Monitoring and Assessment, 66: 293-312.

Visser S M, Sterk G, Ribolzi O. 2004. Techniques for simultaneous quantification of wind and water erosion in semi-arid regions. Journal of Arid Environments, 59: 699-717.

Wan Y, El-Swaify S A. 1998. Characterizing interrill sediment size by partitioning splash and wash processes. Soil Science Society of America Journal, 62: 430-437.

Wang L, Shi Z H, Wang J, et al. 2014. Rainfall kinetic energy controlling erosion processes and sediment sorting on steep hillslopes: a case study of clay loam soil from the Loess Plateau, China. Journal of Hydrology, 512: 168-176.

Xu G C, Li Z B, Li P. 2013. Fractal features of soil particle-size distribution and total soil nitrogen distribution in a typical watershed in the source area of the middle Dan River, China. Catena, 101: 17-23.

Xu J X. 1998. A study of physico-geographical factors for formation of hyperconcentrated flows in the Loess Plateau of China. Geomorphology, 24: 245-255.

Xu J X. 2000. The wind-water two-phase erosion and sediment-producing processes in the middle Yellow River basin, China. Science in China Series D: Earth Science, 43: 176-186.

Xu J X. 2005. Hyperconcentrated flows as influenced by coupled wind-water processes. Science in China Series D: Earth Sciences, 48: 1990-2000.

Yang M Y, Walling D E, Sun X J, et al. 2013. A wind tunnel experiment to explore the feasibility of using beryllium-7 measurements to estimate soil loss by wind erosion. Geochimica et Cosmochimica Acta, 114: 81-93.

Zhang G H, Liu G B, Wang G L, et al. 2011. Effects of vegetation cover and rainfall intensity on sediment-bound nutrient loss, size composition and volume fractal dimension of sediment particles. Pedosphere, 21: 676-684.

Zhao H L, Yi X Y, Zhou R L, et al. 2006. Wind erosion and sand accumulation effects on soil properties in Horqin Sandy Farmland, Inner Mongolia. Catena, 65: 71-79. 